\title{
The Effect of Financial Reporting Quality and Capital Structure on Investment Efficiency in Listed Manufacturing Companies
}

\author{
Gusnario Pranata \\ Faculty of Economics and Business \\ Universitas Padjadjaran \\ Fury Khristianty Fitriyah \\ Faculty of Economics and Business \\ Universitas Padjadjaran
}

\begin{abstract}
Investment is one of the activities of the company in order to achieve the objectives of the company, which is generally to make a profit. Companies are required to properly plan and use resources to achieve optimum investment and avoid inefficient conditions for investment (overinvestment and underinvestment). This research aims to determine the effect of financial reporting quality and capital structure on investment efficiency in manufacturing companies listed on the Indonesia Stock Exchange. The control variables used in this research are company age, operating cash flow ratio, company size, tangibility, and Altman Z-Score. Secondary data from manufacturing sector companies listed on the Indonesia Stock Exchange during the period 2013 to 2015 are used as the research sample. All variables were analyzed using multiple linear regression analysis. The result of this research indicates that with a 5 percent significance level, financial reporting quality and capital structure variables with company age, operating cash flow ratios, company size, tangibility, and Altman Z-Score as the control variables simultaneously and significantly affect investment efficiency while contributing to the effect of 30.3 percent. Partially, financial reporting quality has a positive and significant effect on investment efficiency, and capital structure has a significant effect on investment efficiency.
\end{abstract}

Keywords: Financial reporting quality; Capital structure; Investment efficiency; Stock exchange

\section{Introduction}

A study by the rating agency Standard \& Poor's $(\mathrm{S} \& \mathrm{P})$ in 2014 reported that Indonesian companies may still be underinvested as a consequence of limited capital expenditure, conservative balance sheet management, and lack of profoundness of the financial markets relative to companies in other ASEAN countries (www.thejakartapost.com).

Table 1. Financial Risk Profile of Indonesia Major Companies

\begin{tabular}{lc}
\hline \multicolumn{1}{c}{ Company name } & Financial Risk Profile \\
\hline PT Astra International Tbk. & Modest \\
PT Charoen Pokphand Indonesia Tbk. & Modest \\
PT Gudang Garam Tbk. & Intermediate \\
PT HM Sampoerna Tbk. & Modest \\
PT Indocement Tunggal Prakasa Tbk. & Minimal \\
PT Indofood Sukses Makmur Tbk. & Intermediate \\
PT Jasa Marga (Persero) Tbk. & Aggressive \\
PT Kalbe Farma Tbk. & Minimal \\
\hline
\end{tabular}




\author{
PT Lippo Karawaci Tbk. \\ PT Perusahaan Gas Negara (Persero) Tbk. \\ PT Semen Indonesia (Persero) Tbk. \\ PT Telekomunikasi Indonesia Persero Tbk. \\ PT Unilever Indonesia Tbk. \\ PT United Tractors Tbk. \\ PT XL Axiata Tbk.
}
Aggressive
Minimal
Minimal
Minimal
Modest
Minimal
Intermediate

The report entitled "ASEAN Top Companies" surveyed 100 companies in the Southeast Asia region, including 15 major Indonesian companies. It was found that capital spending on Indonesian companies has been declining significantly since 2011. Capital spending did not grow much between 2011 and 2013. One reason for this case is that these Indonesian companies see a decline in returns that require more investment in order to obtain the same amount of profit. Such companies often pay dividends as much as their capital spending, which then results in "minimal," "modest," or "intermediate" status for the financial risk profile for the majority of companies in this survey. In terms of debt, Indonesian companies use leverage far less than companies in other countries in Southeast Asia.

Figure 1. The Level of Debt-to-EBITDA of ASEAN Countries

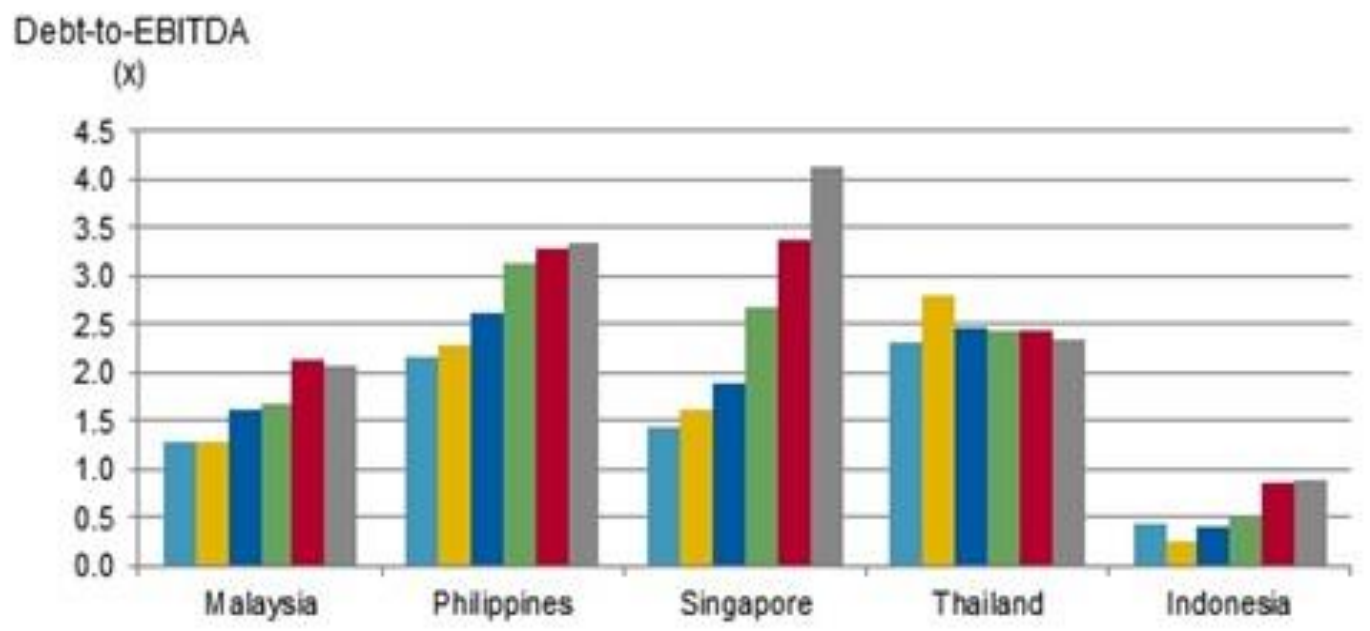

In early 2016, ten countries in the Southeast Asian region that are affiliated with ASEAN (Association of Southeast Asian Nations) began to enact the ASEAN Economic Community (AEC). The enactment of this AEC has led Indonesian companies to face greater competition from companies of other countries that are also members of the ASEAN Economic Community. Indonesia is a developing country with a large population, implying a significant market share. Companies in Indonesia are expected to improve the efficiency of their investments in order to maximize the investment opportunities available to obtain maximum profits. The enactment of the AEC can also lead to higher penetration of capital markets and lending institutions, thereby opening the way for companies to obtain external sources of funding. Companies are expected to use these external funds to invest efficiently.

Based on agency theory, both overinvestment and underinvestment issues can be explained by the existence of information asymmetry among stakeholders. According to Biddle and Hilary (2006), information asymmetry can be reduced by improving the quality of financial reporting. Companies with high financial reporting quality are less likely to 
deviate from the expected level of investment. Investment efficiency can also be affected by the capital structure (Bari and Karamlou, 2014).

\section{Theoretical Framework \& Hypothesis}

Agency Theory

Jensen and Meckling (1976) described that agency relationship begins with a contract between one party as a principal and another as an agent (Godfrey et al., 2010). The principal assigns an agent to provide services for the benefit of the principal. In this assignment, the principal delegates certain authority to make decisions to the agent. According to Anthony and Govindarajan (2007), agency relationships occur when one party (principal) employs another party (agent) to carry out a service, and in that case, delegates the authority to make decisions to the agent. Agents are assigned multiple tasks in order to fulfill the principal's interests.

The relationship between agent and principal can lead to an unbalanced information condition called information asymmetry (Anthony and Govindarajan, 2007). Information asymmetry occurs as the agent is in a position where he/she knows more information about the actual state of the company than the principal. This extra information is called private information. By having this private information, managers can be motivated not to disclose the actual information. This condition is called moral hazard. Information asymmetry can occur if the company owner cannot supervise the entire activities of the manager. The actions by a manager may be different from what the owner wants, this happens because the manager has different preferences from the owner, or in other cases, the manager deliberately cheats the company owner.

\section{Pecking Order Theory}

The pecking order theory, first proposed by Donaldson (1961) and later developed by Myers and Majluf (1984), suggests that information asymmetry between company management and outside investors affects corporate financing decisions. Based on the pecking order theory, managers prefer internal sources of funding as opposed to external sources when the company requires funds. However, in the case where external funding sources are required, managers may certainly specify the safest source of financing. Financing sources through debt are considered to have a lower risk, so the company may choose debt over equity when the company needs external financing sources. Only in a condition where the debt capacity has been attained, companies may then use equity as a source of financing (Ross et al. 2010).

Gitman and Zutter (2015) stated that the pecking order theory assumes that external debt financing is based on an internal funding deficit. Companies prefer to use funds from within the company (internal funding) rather than external funding. Internal funds are obtained from retained earnings generated from the operational activities of the company. When external financing is required, the company may first select the safest securities, i.e., lowestrisk debt, down to riskier debt, hybrid securities such as convertible bonds, preferred stocks, and eventually ordinary shares. There is a consistent dividend policy, where the company must set a constant amount of dividend payment, regardless of how much profit or loss the company receives. The company may draw a current investment portfolio available to anticipate cash supply shortages due to constant dividend policy and fluctuations in profitability, as well as growth opportunities.

\section{Investment Efficiency}

Investment efficiency refers to companies that only take all projects with a positive net present value (NPV) (Zhibiao Zhu et al., 2014; Chen et al., 2011). There are at least two determinants of investment efficiency (Zhibiao Zhu et al., 2014). First, companies must own the capacity to fund and plan to increase their capital for investment opportunities. Second, even if the company can 
raise a sufficient amount of capital and decide to fund, there is no assurance that managers have made the right decisions on investment projects.

Investment efficiency is generated when there is no deviation from the level of investment expected by the company (Chen et al. 2011). However, if the company invests above the optimal value, overinvestment may occur, i.e., the company has made a positive deviation. Conversely, if the company does not do all of the projects with a positive net present value (NPV), then underinvestment may occur, and this means that the company has made a negative deviation.

\section{Financial Reporting Quality}

Based on the Indonesian GAAP (PSAK) No. 1 (Revised 2013) of 2015 concerning the presentation of financial statements, financial statements represent a structured summary of the financial position and financial performance of an entity. According to Weygandt et al. (2011), financial statements are the final results of accounting activities consisting of recording, grouping, reporting, and interpreting, which include the historical and current data of the company in currency units intended for the company's external parties for decision-making. Biddle et al. (2009) defined financial reporting quality as the accuracy of financial statements in conveying the actual information about the operational activities of the company.

Accounting information is useful for both internal and external parties of the company (Ferrell et al., 2014). Parties within the company, such as managers, use accounting information in planning and directing company activities. This accounting information is immensely helpful in corporate budgeting activities for managers. Meanwhile, outsiders use this accounting information to observe the financial situation of the company. This information is hugely beneficial for outside parties, such as investors or creditors, when making decisions about funds in the company.

\section{Capital Structure}

Capital Structure is equity and debt funding from a company (Subramanyam, 2014). The capital structure indicates the sources of funding for the company originated. Financial stability and bankruptcy risk of a company depend on the source of funding of the company as well as the type and the number of the company's assets.

Margaretha (2014) defined a capital structure as a framework that describes the company's permanent financing sources consisting of long-term debt and equity. Gitman and Zutter (2015) also stated that the total capital of a company consists of long-term debt and equity. According to Fahmi (2014), capital structure is a description of the form of corporate financial proportions, which is between owned capital from long-term liabilities and equity, which is a source of funding for a company. The need for funds to strengthen the company's capital structure can be sourced internally and externally, given that the required source of funds originates from safe positions. This source has a thrust value in strengthening the company's financial capital structure. In the sense that when the funds are used to strengthen the company's capital structure, the company can control the capital effectively and efficiently and on target.

Capital structure is one of the most complex areas in funding decision making due to its interrelationship with other funding decision variables (Gitman and Zutter, 2015). Poor decisions on the capital structure resulting in high capital costs, thereby reducing the Net Present Value (NPV) of a project and making other projects undesirable. Effective capital structure decisions can reduce the cost of capital to increase the Net Present Value (NPV) of a project and make many projects acceptable, thus increasing the value of the company.

\section{Research Framework}

Figure 2 below illustrates the framework for this research: 
Figure 2. Theoretical Framework

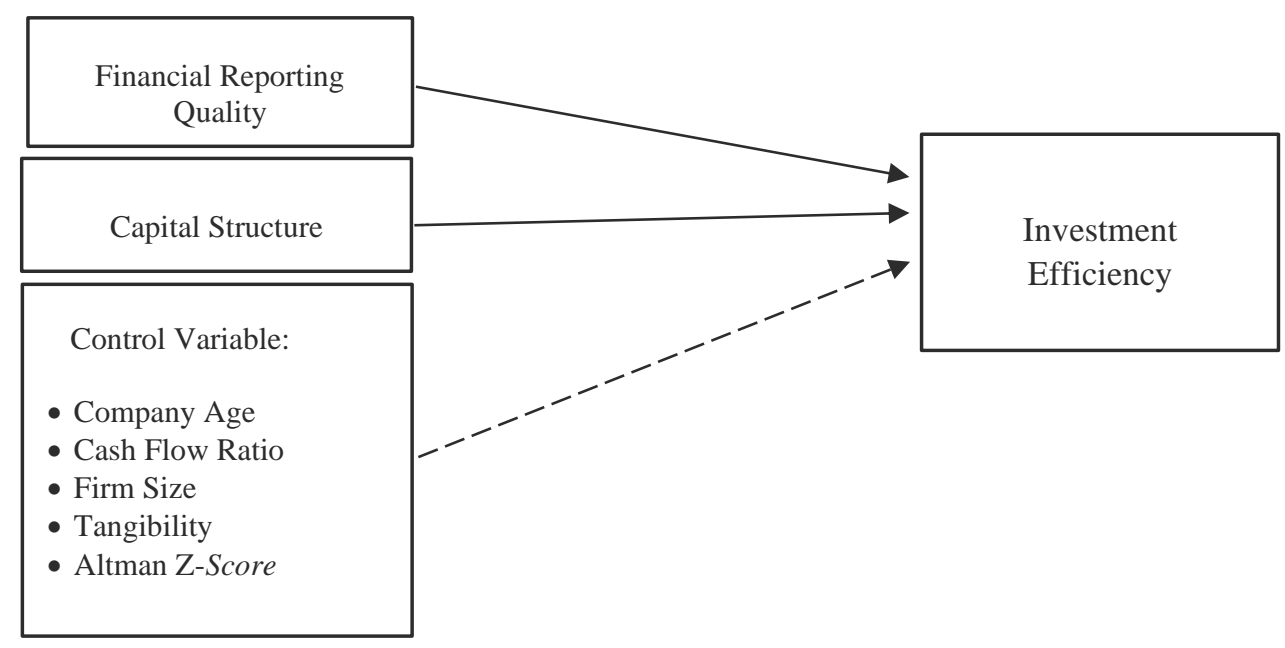

The Effect of Financial Reporting Quality on Investment Efficiency

The relationship between financial reporting quality and investment efficiency is related to the reduction of information asymmetry between the company and external parties as to the capital provider (Biddle et al., 2009). Information asymmetry is one of the factors influencing the investment of the company because it will make less quality investment decisions (Sari and Suaryana, 2014). Based on the agency theory perspective, there are numerous ways of reducing information asymmetry, such as disclosure of financial reporting quality, which allows managerial activities to be adequately controlled to reduce opportunistic managerial behavior (Rahmawati and Harto, 2014).

Biddle et al. (2009) examined the effect of financial reporting quality on investment inefficiency, namely overinvestment and underinvestment conditions in US stock exchange-listed companies, while Chen et al. (2011) examined the private companies in emerging markets. These studies show that the quality of financial reporting helps companies that experience underinvestment problems and companies that experience overinvestment problems.

Hypothesis 1: Financial reporting quality has a positive effect on investment efficiency.

The Effect of Capital Structure on Investment Efficiency

A company needs funds to carry out its business plan. Funding activities refer to the methods used by companies to obtain money to fund their needs (Subramanyam, 2014). The company has the potential to determine the success or failure of a business, so the company must have the ability to take care of activities related to obtaining and managing their financial resources. The role of debt in reducing the manager's independence and disciplining managers' investment decisions has been discussed in several studies (Myers, 1977; Jensen, 1986). D'Mello and Miranda (2010) in Gomariz and Ballesta (2013) have found supporting evidence regarding the role of debt in reducing the problem of overinvestment.

Bari and Karamlou (2014) conducted a study on the relationship between capital structure (leverage) and investment efficiency in 87 companies listed on the Tehran Stock Exchange. The results revealed that a 
significant negative relationship occurs between capital structure (leverage) and investment efficiency. This result indicated that a lower level of leverage, higher investment efficiency of a company, and vice versa. Research on the relationship between capital structure and investment has also been carried out by Hackbart and Mauer (2011). Result from research by Hackbart and Mauer (2011) indicated that a simultaneous decision to select an optimal capital structure and a structure that prioritizes debt might assist the implementation of best investment policies.

Hypothesis 2: Capital structure affects investment efficiency.

Hypothesis 3: Financial reporting quality and capital structure along with company age, operating cash flow ratio, company size, tangibility, and Altman Z-Score as a control variable affect investment efficiency.

\section{Research Methodology}

\section{Population and Research Samples}

The population in this research is manufacturing companies listed on the Indonesia Stock Exchange (IDX). The sample was selected through a purposive sampling method, which is the technique of selecting samples from a population with certain considerations that adhere to the desired criteria (Sugiyono, 2011). The criteria used on the sample selection in this research are as follow:

1. Manufacturing sector companies listed on the Indonesia Stock Exchange between the period of 2013 and 2015.

2. Companies that issue financial statements or annual reports expressed in Rupiah (Rp).

3. Companies that publish financial reports or annual reports that have been audited by independent auditors in the period between 2011 and 2015 through the Indonesia Stock Exchange website (www.idx.co.id).
4. Companies that provide financial reports with all the information needed by all variables in this study.

\section{Research variables}

The dependent variable of this research is investment efficiency. The following model developed by Chen et al. (2011) as the improvement of the design model by Biddle et al. (2009) for calculating investment efficiency:

Investment $_{i, t}=\beta_{0}+\beta_{1} \mathrm{NEG}_{i, t-1}+\beta_{2} \%$ SalesGrowthi, ${ }_{t-}$ ${ }_{1}+\beta_{3} \mathrm{NEGi}_{,-t-1} * \%$ SalesGrowthi,,$-1+\varepsilon_{i, t}$, Where:

- Investment, $\mathrm{t}_{\mathrm{t}}=$ Total investment of company $i$ in year t. Measured by the increase in fixed assets and research and development minus sales of fixed assets divided by total assets of the previous year.

- $\%$ SalesGrowth $\mathrm{i}_{\mathrm{i}, \mathrm{t}}=$ Rate of change in sales revenue in a company i from $\mathrm{t}-2$ to $\mathrm{t}-1$.

- $\mathrm{NEG}_{\mathrm{t}-1}=$ Value 1 for negative sales revenue growth and 0 for other than negative sales revenue growth.

The investment model is estimated crosssectionally for each year. The residuals of the regression reflect the deviation from the expected level of investment. The dependent variable of this research is the absolute value of the residual value multiplied by -1 , so that a higher value has a meaning of higher investment efficiency $($ IEi, $\mathrm{t}=-|\hat{\varepsilon} \mathrm{i}, \mathrm{t}|)$.

The first independent variable is financial reporting quality, which is measured using the following proxy developed by McNichols and Stubben (2008) and Stubben (2010):

$$
\Delta \mathrm{AR}_{i, t}=\beta_{0}+\beta_{1} \Delta \operatorname{Sales}_{i, t}+\varepsilon_{i, t}, \text { Where: }
$$

- $\Delta \mathrm{AR}_{\mathrm{i}, \mathrm{t}}=$ Changes in accounts receivable for the company $i$ in year $t$ divided by total assets of the previous year.

- AlSales $_{\mathrm{i}, \mathrm{t}}=$ Changes in sales revenue for the company $i$ in year $t$ divided by total assets of the previous year.

The model of the above equation is estimated for each year. The residual value of the equation is discretionary revenue, which is 
the change in receivables that are not explained by sales growth. The quality of financial reporting in this study is the absolute value of discretionary revenue multiplied by -1 , so that the highest value may indicate high financial reporting quality (FRQi, $\mathrm{t}=-|\hat{\varepsilon} \mathrm{i}, \mathrm{t}|)$. The second independent variable is the capital structure measured by the following formula:

Capital Structure $=($ Total Debt $) /($ Total Asset $)$

The control variables in this research consisted of company age ( $\mathrm{Ln} *$ company age), operating cash flow ratio (operating cash flow / total assets), company size ( $\mathrm{Ln} *$ sales revenue), tangibility (tangible fixed assets / total assets), and Altman Z-Score $(\mathrm{Z}=1.2 \mathrm{X} 1+1.4 \mathrm{X} 2+3.3$ $\mathrm{X} 3+0.6 \mathrm{X} 4+1.0 \mathrm{X} 5$ where $\mathrm{X} 1$ is working capital / total assets; X2 retained earnings / total assets; X3 EBIT / total assets; X4 market value of equity / book value of liabilities; and X5 are sales / total assets). The multiple regression model in this research is as follows:

$$
\begin{gathered}
\mathrm{IE}_{i, t}=\beta_{0}+\beta_{1} \mathrm{FRQ}_{i, t}+\beta_{2} \mathrm{CS}_{i, t}+\beta_{3} \mathrm{LNAge}_{i, t}+ \\
\beta_{4} \mathrm{CFO}_{-} \mathrm{TA}_{i, t}+\beta_{5} \mathrm{LNSize}_{i, t}+\beta_{6} \text { Tang }_{i, t}+\beta_{7} \mathrm{Z}_{i, t} \\
+\varepsilon_{i, t}
\end{gathered}
$$

$\mathrm{IE}=$ Investment efficiency
FRQ $=$ Financial reporting quality

$\mathrm{CS}=$ Capital structure

LNAge $=$ Company age

CFO_TA $=$ Operating cash flow ratio

LNSales $=$ Company size

Tang $=$ Tangibility

$\mathrm{Z}=$ Altman Z-Score

$\beta 0=$ constant

$\beta 1-\beta 7=$ Regression coefficient

$\varepsilon=$ Residual $/$ error

\section{Results and Discussion}

\section{Description of Research Samples}

The research sample includes manufacturing companies listed on the Indonesia Stock Exchange (IDX) between 2013 and 2015. The sample is obtained using a purposive sampling method which is based on certain criteria. The number of observations between 2013 and 2015 is 199 companies

Table 2. Research Sample Criteria

\begin{tabular}{lc}
\hline \multicolumn{1}{c}{ Criteria } & $\begin{array}{c}\text { Number of } \\
\text { Companies }\end{array}$ \\
\hline $\begin{array}{l}\text { Manufacturing sector companies listed on the Indonesia Stock Exchange between } \\
\text { the period of } 2013 \text { and } 2015\end{array}$ & 143 \\
Companies that issue financial statements or annual reports expressed in Rupiah & $(27)$ \\
(Rp) & $(24)$ \\
Companies that publish financial reports or annual reports that have been audited \\
by independent auditors in the period between 2011 and 2015 through the \\
Indonesia Stock Exchange website (www.idx.co.id) \\
$\begin{array}{lc}\text { Companies that do not provide financial reports with all the information needed } \\
\text { by all variables in this study. }\end{array}$ \\
$\begin{array}{l}\text { Companies that fulfill the criteria } \\
\text { Total samples that can be used in the overall study (3 years) }\end{array}$ \\
$\begin{array}{l}\text { Outliers } \\
\text { Total data }\end{array}$ \\
\hline
\end{tabular}

\section{Discussion of Research Results}

The findings of the analysis of the classical assumptions indicate that the regression model has met the criterion for normality, autocorrelation, heteroscedasticity, and multicollinearity test. The hypothesis testing is 
then conducted using multiple linear regression after completion of the classical assumption test.
The findings of the regression model are presented below.

Table 3. Estimation Results of Regression Equations

\begin{tabular}{lc}
\hline Variabel & $\boldsymbol{\beta}$ \\
\hline Constant & $-0,058$ \\
FRQ & 0,162 \\
CS & $-0,056$ \\
LNAge & 0,002 \\
CFO_TA & 0,036 \\
LNSize & 0,003 \\
Tang & $-0,025$ \\
Z & $-0,008$ \\
\hline
\end{tabular}

Based on the results of calculations in the table above, we obtain the following form of multiple linear regression equations:

$\mathrm{IE}_{i, t}=-0,058+0,162 \mathrm{FRQ}-0,056 \mathrm{CS}+$ 0,002LNAge + 0,036CFO_TA + 0,003LNSize $-0,025$ Tang $-0,008 \mathrm{Z}$

The values in the regression equation above can be explained as follows:

- $\beta 0=-0,058$ indicating that when all independent variables, i.e., financial reporting quality (X1) and capital structure (X2), as well as all control variables namely company age, operating cash flow ratios, company size, tangibility, and Altman Z-Score, are 0 (zero) or no change, then the predicted average investment efficiency are worth $-0,058$.

- $\beta 1=0.162$, meaning that the variable of financial reporting quality (X1) has increased by one unit while the value of the capital structure variable (X2) and the age control variable of the company, operating cash flow ratios, company size, tangibility, and Altman ZScore are assumed to be constant, then the value of investment efficiency ( $\mathrm{Y}$ ) may increase by 0.162 units.

- $\beta 2=-0,056$, meaning that if the capital structure variable (X2) increases by one unit while the value of the financial reporting quality $(\mathrm{X} 1)$ and the age control of the company, operating cash flow ratio, company size, tangibility, and Altman Z-Score are assumed constant, the value of investment efficiency $(Y)$ may decrease by 0.056 units.
- $\beta 3=0.002$, indicating that the age control of the company has increased by one unit while the value of financial reporting quality (X1) and capital structure (X2), as well as the control variable operating cash flow ratio, company size, tangibility, and Altman Z-Score, are assumed constant, the value of investment efficiency (Y) may increase by 0.002 units.

- $\beta 4=0.036$, meaning that the control variable of operating cash flow ratio has increased by one unit while the value of the independent variable financial reporting quality (X1) and capital structure (X2), as well as the variables controlling the age of the company, company size, tangibility, and Altman Z-Score, are assumed constant, the value of investment efficiency (Y) may increase by 0.036 units.

$-\beta 5=0.003$, indicating that if the company size has increased by one unit while the value of financial reporting quality (X1) and capital structure (X2) and the control variable of age, operating cash flow ratio, tangibility, and Altman Z-Score assumed constant, the value of investment efficiency ( $\mathrm{Y}$ ) may increase by 0.003 units.

- $\beta 6=-0.025$, meaning that if the tangibility control variable increases by one unit while the value of financial statements quality (X1) and capital structure (X2) as well as control variables of company age, operating cash flow ratios, company size, and Altman Z-Score are assumed to be constant, then the value of 
investment efficiency (Y) may decrease by 0.025 units.

- $\beta 7=-0.008$, indicating that the Altman ZScore has increased by one unit while the value of financial reporting quality (X1) and capital structure (X2) as well as the control variable of age, operating cash flow ratio, company size, and tangibility is assumed to be constant, then the value of investment efficiency (Y) may decrease by 0.008 units.

Partial Hypothesis Testing $X_{I}$

Table 4. t-Test for X1

\section{ater}

$\mathrm{FRQ} \rightarrow \mathrm{IE}$

Based on the table above, it can be identified that the $t_{\text {count }}$ obtained by the financial reporting quality is 2,289 . This value is compared to the table value in the distribution table t. With $\alpha=0.05, \mathrm{df}=\mathrm{n}-\mathrm{k}=199-8=191$, for a one-sided test, a $t_{\text {table }}$ value of 1.653 was obtained. From these values, it can be identified that the $\mathrm{t}_{\text {count }}$ obtained at 2.22899 is more than the value of 1.653. In line with the hypothesis testing criteria that $\mathrm{HO}$ is rejected and $\mathrm{Ha}$ is accepted, it means that partially, financial reporting quality has a positive and significant effect on investment efficiency.

In this study, financial reporting quality is measured by the absolute value of discretionary revenue multiplied by -1 , while the investment efficiency is measured by the absolute value of the deviation of the investment model multiplied by -1 . With these results, it can be identified that the lower the discretionary revenue that occurs in a company, the higher the financial reporting quality, the lower the value of deviations from the investment model, which means the higher the investment efficiency of the company.

It can be inferred that the high quality of financial reporting can improve investment efficiency. These results are in tune with previous research conducted by Rahmawati and Harto (2014) and Sakti and Septiani, (2015).
H0: $\beta 1 \leq 0$, i.e. partially, financial reporting quality does not have a positive and significant effect on investment efficiency.

Ha: $\beta 1>0$, i.e. partially, financial reporting quality has a positive and significant effect on investment efficiency.

The significance level $(\alpha)$ used is $5 \%$ or 0.05 . Criteria partial test decision making:

1) Accept $\mathrm{HO}$ and reject $\mathrm{Ha}$ if $\mathrm{t}_{\text {count }} \leq t_{\text {table }}$

2) Reject $H 0$ and accept Ha if $t_{\text {count }}>t_{\text {table }}$
$\mathbf{T}_{\text {count }}$

2,289

1,653

These results also support previous research conducted by Biddle et al. (2009), Chen et al. (2011), Gomariz and Ballesta (2013), and Sari and Suaryana (2014).

The relationship between financial reporting quality and investment efficiency is related to the reduction of information asymmetry between the company and external parties as to the capital provider (Biddle et al., 2009). Information asymmetry is one of the factors that affect the investment of the company as it creates investment decisions of less quality (Sari and Suaryana, 2014).

According to Biddle et al. (2009), information asymmetry between companies and capital providers may reduce investment efficiency by increasing uncertainty such as moral hazard and adverse selection, which can increase investment inefficiency. The existence of this information asymmetry may lead to a failure in achieving the initial investment goal of the company, i.e., increasing shareholder wealth. Based on the agency theory perspective, there are various ways to alleviate information asymmetry such as disclosure of financial reporting quality that helps in better supervision of managerial activities, to reduce opportunistic managerial behavior (Rahmawati and Harto, 2014). 
High-quality financial reporting can relieve the problem of information asymmetry and diminish overinvestment and underinvestment issues. It can be due to the high quality of financial reporting that allows managers to make investment decisions through better project identification and provides accounting statistics that are more appropriate for internal decision making (McNichols and Stubben, 2008). High-quality financial reporting enables better supervision; therefore, managers become more responsible (Gomariz and Ballesta, 2013).

Table 5. t-test outcome for hypothesis 2

\section{Partial Hypothesis Testing $X_{2}$}

H0: $\beta 2=0$ i.e. partially, capital structure has no significant effect on investment efficiency.

Ha: $\beta 2 \neq 0$ i.e. partially, capital structure has a significant effect on investment efficiency.

The significance level $(\alpha)$ used is $5 \%$ or 0.05 . Criteria for making two-party partial test decisions:

1) Accept $\mathrm{HO}$ and reject $\mathrm{Ha}$ if $\mathrm{t}_{\text {count }} \leq \mathrm{t}_{\text {table }}$ or if $\mathrm{t}_{\text {count }} \geq \mathrm{t}_{\text {table }}$

2) Reject $\mathrm{HO}$ and accept $\mathrm{Ha}$ if $t_{\text {count }}>t_{\text {table }}$ or if $\mathrm{t}_{\text {count }}<\mathrm{t}_{\text {table }}$

\begin{tabular}{ccc}
\hline Model & $\mathbf{T}_{\text {count }}$ & $\mathbf{t}_{\text {table }}$ \\
\hline $\mathrm{CS} \rightarrow \mathrm{IE}$ & $-4,243$ & $\pm 1,972$ \\
\hline
\end{tabular}

Based on the table above, it can be identified that the $t_{\text {count }}$ obtained by the capital structure is $-4,243$. This value is compared with the table value in the distribution table $t$. With $\alpha=0.05, \mathrm{df}=\mathrm{n}-\mathrm{k}=199-8=191$, for a twosided test obtained a table value of \pm 1.972 . From these values, it can be identified that the $\mathrm{t}$-value obtained is $-4,243$, less than the value of -table -1,972. Under the hypothesis testing criteria to reject $\mathrm{HO}$ and accept $\mathrm{Ha}$, hence, partially, the capital structure has a significant effect on investment efficiency.

In this study, capital structure is measured by the ratio of total debt to total assets, while investment efficiency is measured by the absolute value of the deviation from the investment model multiplied by -1 . With these results, it can be identified that the composition of the ratio between total debt to total assets in a company can significantly affect the value of the deviation of the investment model of a company that indicates the high and low investment efficiency of the company.

It can be concluded that the capital structure has a significant effect on investment efficiency. This result is consistent with the results of research conducted by Samaneh Bari and Meisam Karamlou in 2014. Bari and Karamlou (2014) conducted a study concerning the relationship between capital structure and investment efficiency in 87 companies listed on the Tehran Stock Exchange. The result revealed that there is a significant relationship between capital structure and investment efficiency. Bari and Karamlou (2014) found a significant effect with a negative direction between the capital structure as measured by leverage and investment efficiency, which shows that the lower the level of leverage, the higher the investment efficiency of a company.

\section{Simultaneous Effect Hypothesis Test}

Simultaneous effect testing aims to prove whether the two independent variables consisting of financial reporting quality and capital structure, controlled by company age, operating cash flow ratios, company size, tangibility, and Altman Z-Score significantly affects investment efficiency in manufacturing companies listed on the Indonesia Stock Exchange between the period of 2013 and 2015.

The hypotheses tested are as follows:

- H0: $\beta i=0$, i.e. simultaneously, the two independent variables consisting of financial reporting quality and capital structure with company age, operating cash flow ratio, company size, tangibility, and 
Altman Z-Score as control variables do not significantly affect investment efficiency.

- Ha: $\beta i \neq 0$, i.e. simultaneously, the two independent variables consisting of financial reporting quality and capital structure with company age, operating cash flow ratio, company size, tangibility, and Altman Z-Score as a control variable significantly affect investment efficiency. The significance level $(\alpha)$ used is $5 \%$ or 0.05 . Criteria for making simultaneous test decisions:

1) Accept $\mathrm{H} 0$ and reject $\mathrm{Ha}$ if the value of $F_{\text {count }}$ $\leq \mathrm{F}_{\text {table }}$

2) Reject $\mathrm{HO}$ and accept $\mathrm{Ha}$ if $\mathrm{F}_{\text {count }}>\mathrm{F}_{\text {table }}$

Table 6. F-test Output

\begin{tabular}{lll}
\hline $\mathbf{F}_{\text {count }}$ & $\mathbf{F}_{\text {table }}$ & Decision \\
\hline 11,881 & 2,06 & $\mathrm{H}_{\mathrm{a}}$ accepted \\
\hline
\end{tabular}

Based on the table above, it is known that the $\mathrm{F}_{\text {count }}$ value obtained was 11,881 . This value is compared with the $F_{\text {table }}$ value in the distribution table F. With $\alpha=0.05, \mathrm{db} 1=7$ and $\mathrm{db} 2=191$, a $\mathrm{F}_{\text {table }}$ value of 2.06 is obtained. From these values, it can be identified that the calculated $F_{\text {count }}$ value of 11.881 is greater than the $\mathrm{F}_{\text {table }}$ value of 2.06. Under the hypothesis testing criteria that $\mathrm{HO}$ is rejected and $\mathrm{Ha}$ is accepted, it means that the two independent variables consisting of financial reporting quality and capital structure with company age, operating cash flow ratio, company size, tangibility, and Altman Z-Score simultaneously and significantly affects investment efficiency.

It can be concluded that the two independent variables, i.e., the amount of discretionary revenue as a proxy for financial reporting quality and capital structure measured by the composition of the ratio between total debt to total assets in a company, as well as five control variables, namely the company age as measured by the year the company has been established, the ratio of operating cash flow to total assets, the size of the company measured by the natural logarithm of total company revenue, tangibility measured by the ratio of tangible fixed assets to total assets, and the Altman Z-Score which is a figure to predict the risk of bankruptcy, significantly affects the value of the deviation of the investment model of a company that indicates the high and low efficiency of the company's investment.
The relationship between financial reporting quality and investment efficiency is related to the reduction of information asymmetry between the company and external parties as to the parties providing the capital (Biddle et al., 2009). Information asymmetry is one of the factors that affect the company's investment because it creates less quality investment decisions (Sari and Suaryana, 2014).

The relationship between capital structure and investment efficiency is related to how companies fund an investment opportunity. Investment efficiency refers to companies that merely take all projects with a positive net present value (NPV) (Zhibiao Zhu et al., 2014; Chen et al. 2011). There are at least two determinants of investment efficiency (Zhibiao Zhu et al., 2014). First, companies must own financing capacity and plan to increase capital for investment opportunities. Second, even if the company can raise a sufficient amount of capital and plan of financing, there is no guarantee that managers have made the right decisions regarding investment projects.

The ability to minimize information asymmetry through improving the quality of financial reporting as well as the ability to obtain funds and manage funds to finance company activities reflected by how the capital structure used by the company is shown to have a significant effect on how the company's investment efficiency with the company's age, current ratios operating cash, company size 
tangibility, and Altman Z-Score are used as control variable

Table 7. Coefficient of Determination

\begin{tabular}{cccc}
\hline Model & $\mathbf{R}$ & R Square & Adjusted R Square \\
\hline 1 & 0,551 & 0,303 & 0,278 \\
\hline
\end{tabular}

Based on the data presented in the above table, R2 is obtained at a value of 0.303 or $30.3 \%$. This value shows that the two independent variables tested consisted of financial reporting quality and capital structure with the company age, operating cash flow ratios, company size, tangibility, and Altman ZScore as a control variable contributes several effects on investment efficiency in manufacturing companies listed on the Indonesia Stock Exchange between the period of 2013 and 2015 with the value of $30.3 \%$, while the remaining $69.7 \%$ is a substantial contribution of effect from other factors that are not examined.

\section{Conclusion}

Based on the results of data analysis and discussion, we draw the following conclusions:

1. Partially, financial reporting quality has a positive and significant effect on investment efficiency in manufacturing companies listed on the Indonesia Stock Exchange between the period of 2013 and 2015.

2. Partially, capital structure has a significant effect on investment efficiency in manufacturing companies listed on the Indonesia Stock Exchange between the period of 2013 and 2015.

3. Simultaneously, the two independent variables consisting of the quality of financial reporting and capital structure with the company age, operating cash flow ratio, company size, tangibility, and Altman Z-Score as a control variable have a significant effect on investment efficiency with a contribution of $30.3 \%$, whereas the remaining $69.7 \%$ is contributed by other variables which are not examined in this research.

\section{Direction for Future Research}

Based on the discussion and conclusions outlined above, we would like to provide several recommendations for future research:

1. Future studies are expected to add the number of companies other than manufacturing sectors or extend research periods or even add other variables that are assumed to have certain effects on investment efficiency.

2. Future research can add or use other proxies to measure financial reporting quality. Another proxy for measuring financial reporting quality that can be used is the accrual quality of Dechow and Dichev (2002). Measurement with the model developed by Dechow and Dichev (2002) is frequently used in various studies. Measurement with this proxy is expected to have a more significant effect on investment efficiency, as has been done by Rahmawati and Harto (2014).

\section{References}

Anthony, R. N., \& Govindarajan, V. (2007). Management Control Systems. New York: McGraw-Hill Education.

Bari, S., \& Karamlou, M. (2014). Capital Structure and Investment Efficiency: Empirical Evidence from Companies Listed in Tehran Stock Exchange. Arth Prabandh: A Journal of Economics and Management, 3, 80-93.

Biddle, G. C., \& Hilary, G. (2006). Accounting Quality and Firm-Level Capital 
Investment. The Accounting Review, 81, 963-982.

Biddle, G. C., Hilary, G., \& Verdi, R. S. (2009). How Does Financial Reporting Quality Relate to Investment Efficiency?. Journal of Accounting and Economics, 48, 112-131.

Chen, F., Hope, O.-K., Li, Q., \& Wang, X. (2011). Financial Reporting Quality and Investment Efficiency of Private Firms in Emerging Markets. The Accounting Review, 86, 1255-1288.

Dechow, P., Dichev, I., 2002. The quality of accruals and earnings: the role of accrual estimation errors. The Accounting Review, 77, 35-59.

Fahmi, I. (2014). Analisis Kinerja Keuangan: Panduan bagi Akademisi, Manajer, dan Investor untuk Menilai dan Menganalisis Bisnis dari Aspek Keuangan (Financial Performance Analysis: A Guide for Academics, Managers, and Investors to Assess and Analyze Businesses from Financial Aspects). Bandung: Alfabeta.

Ferrell, O. C., Hirt, G., \& Ferrell, L. (2014). Business: A Changing World. New York: McGraw-Hill Education.

Gitman, L. J., \& Zutter, C. J. (2015). Principles of Managerial Finance. England: Pearson Education.

Godfrey, J., Hodgson, A., Tarca, A., Hamilton, J., \& Holmes, S. (2010). Accounting Theory. Milton: John Wiley and Sons Australia.

Gomariz, M. C., \& Ballesta, J. S. (2013). Financial reporting quality, debt maturity and investment efficiency. Journal of Banking \& Finance, 40, 494-506.

Hackbarth, D., \& Mauer, D. C. (2011). Optimal Priority Structure, Capital Structure, and Investment. The Review of Financial Studies, 25, 747-796.
Margaretha, F. (2014). Dasar-dasar Manajemen Keuangan (Fundamentals of Financial Management). Jakarta: Dian Rakyat.

McNichols, M. F., and Stubben S. R.(2008). Does earnings management affect firms' investment decisions?. The Accounting Review 83 (6): 1571-1603.

Rahmawati, A. D., \& Harto, P. (2014). Analisis Pengaruh Kualitas Pelaporan Keuangan dan Maturitas Utang Terhadap Efisiensi Investasi (Analysis of the Effect of Financial Reporting Quality and Debt Maturity on Investment Efficiency). Diponegoro Journal of Accounting, 3, 1-12.

Ross, S. A., Westerfield, R. W., \& Jaffe, J. (2010). Corporate Finance. New York: McGraw-Hill Companies.

Sakti, A. M., \& Septiani, A. (2015). Pengaruh Kualitas Pelaporan Keuangan dan Jatuh Tempo Utang Terhadap Efisiensi Investasi (The Effect of Quality of Financial Reporting and Debt Maturity on Investment Efficiency). Diponegoro Journal of Accounting, 4, 1-10.

Sari, L. N., \& Suaryana, I. A. (2014). Pengaruh Kualitas Laporan Keuangan Pada Efisiensi Investasi Perusahaan Pertambangan (Effect of Financial Statement Quality on Investment Efficiency of Mining Companies). EJurnal Akuntansi Universitas Udayana, 8, 524-537.

Sekaran, U., \& Bougie, R. (2010). Research Methods for Business: A Skill Building Approach. UK: John Wiley \& Sons.

Sipahutar, T. (2014, Oktober 10). Indonesian firms still underinvest compared to ASEAN peers. Dipetik September 20, 2015, dari TheJakartaPost: http://www.thejakartapost.com/news/2 014/10/10/indonesian-firms-stillunderinvest-compared-aseanpeers.html 
Standard \& Poor's. (2014, September 9). ASEAN Top Companies: Major Credit Highlights. Dipetik September 20, 2015, dari Global Credit Portal: https://www.globalcreditportal.com/ra tingsdirect/renderArticle.do?articleId= 1357932\&SctArtId $=261402 \&$ from $=C$ M\&nsl_code=LIME\&sourceObjectId $=8803775 \&$ source RevId $=1 \&$ fee_ind $=$ N\&exp_date $=20240908-13: 15: 05$

Standard \& Poor's. (2015, Agustus 11). ASEAN Top Companies: Debt Keeps Rising While Growth Is Fading. Dipetik September 20, 2015, dari Global Credit Portal: https://www.globalcreditportal.com/ra tingsdirect/renderArticle.do?articleId= 1432932\&SctArtId=333908\& from $=\mathrm{C}$

Zhu, Z., Wang, F., Zhang, M., \& Hoffmire, J. (2014). Financial Reporting Quality, Collateral Value, and Investment Efficiency: Evidence from China. Advanced Management Science, 3, 5665.
M\&nsl_code=LIME\&sourceObjectId $=9288931 \&$ sourceRevId $=1 \&$ fee_ind $=$ N\&exp_date $=20250811-18: 53: 55$

Stubben, S. R. (2010). Discretionary Revenues as a Measure of Earnings Management. The Accounting Review, 85, 659-717.

Subramanyam, K. R. (2009). Financial Statement Analysis. New York: McGraw-Hill Education.

Sugiyono. (2011). Metode Penelitian Kuantitatif, Kualitatif, dan $R \& D$ (Quantitative, Qualitative, and R\&D Research Methods). Bandung: Alfabeta.

Weygandt, j. J., Kimmel, P. D., \& Kiesso, D. E. (2011). Financial Accounting: IFRS Edition. USA: John Wiley \& Sons. 